September 2006

\title{
The Ottoman Documents and the Genocidal Policies of the Committee for Union and Progress (Ittihat ve Terakki) toward the Armenians in 1915
}

Taner Akçam

Follow this and additional works at: https://digitalcommons.usf.edu/gsp

\section{Recommended Citation}

Akçam, Taner (2006) "The Ottoman Documents and the Genocidal Policies of the Committee for Union and Progress (ittihat ve Terakki) toward the Armenians in 1915," Genocide Studies and Prevention: An International Journal: Vol. 1: Iss. 2: Article 5.

Available at: https://digitalcommons.usf.edu/gsp/vol1/iss2/5

This Articles is brought to you for free and open access by the Open Access Journals at Digital Commons @ University of South Florida. It has been accepted for inclusion in Genocide Studies and Prevention: An International Journal by an authorized editor of Digital Commons @ University of South Florida. For more information, please contact digitalcommons@usf.edu. 


\title{
The Ottoman Documents and the Genocidal Policies of the Committee for Union and Progress (ittihat ve Terakki) toward the Armenians in 1915
}

\author{
Taner Akçam \\ University of Minnesota
}

\begin{abstract}
The author analyzes the Ottoman Archives as a source of information on the Armenian Genocide of 1915. He discusses the contradictory positions of two broad groups of scholars on the reliability of these archives, concluding that the Ottoman Archives agree with the information found in the archives of the United States, Britain, Germany, and Austria. He discusses the various categories of Ottoman documents, which mostly came out during the trials related to the Armenian Genocide, which took place from 1919 to 1921, and makes clear that there was a wide-ranging cleansing operation of the archives after the armistice in 1918. The author explores the reliability of this evidence and, based on the existing documents that remain, tries to reconstruct the structure and implementation of the genocide. He concludes that the Ottoman documents clearly show the genocidal intent of the Ottoman authorities and puts the Armenian genocide within the broader context of an overarching plan to homogenize the ethnic population of Anatolia.
\end{abstract}

This article seeks to shed light on the issue of the "cleansing of the Ottoman archives" and to summarize some of the remaining documents, which could be classified as direct evidence illustrating the genocidal intent of the policies enacted by the Committee for Union and Progress (CUP) against the Armenians in $1915 .^{1}$

\section{The Categories of Ottoman Materials}

Seven categories of Ottoman documents attest that during World War I, the CUP maintained and executed a policy of extermination toward the Armenians:

(1) The Prime Ministerial Archive (Başbakanlık Arşivi), and especially the archives of the Ministry of the Interior. When scholars speak commonly of the "Ottoman Archives," they essentially refer to the archive in Istanbul known as the Prime Ministerial Archives, or BOA (Başbakanlık Osmanlı Arşivleri). The documents of the Interior Ministry there are considered the most significant. ${ }^{2}$

(2) Trial transcripts of the cases brought before the Military Tribunal (1919-1921) against the central and provincial directors of the CUP, as published in the official register of court cases, the Ottoman Gazette (Takvim-i Vekayi). Of the twelve chronicled cases, we have complete transcripts of the two trials against the responsible members of the CUP's Central Committee, the "Special Organization" (Tesskilat-1 Mahsusa), and the trial of the wartime cabinet ministers, comprising the minutes of the hearings, indictments, and final

Taner Akçam, "The Ottoman Documents and the Genocidal Policies of the Committee for Union and Progress (Ittihat ve Terakki) toward the Armenians in 1915." Genocide Studies and Prevention 1, 2 (September 2006): 127-148. (C) 2006 Genocide Studies and Prevention. 
court rulings, fourteen in all. In one of the trials, that against the Party secretaries (Katib-i Mesuller), only the first three of thirteen hearings, along with the final ruling, were published in the Ottoman Gazette. The remaining nine trials are documented either only as final court rulings, as in the Yozgat and Trabzon trials, or as Sultan's Approvals, as in the Erzincan and Bayburt trials.

(3) The Istanbul press, 1919-1922. Contemporary newspapers published detailed information about sixty-three separate trials, including complete transcripts—which appear nowhere else-of the Erzincan and Bayburt trials. ${ }^{3}$ The criminal charges included the murder and deportation of Armenians and the misappropriation of their possessions. Presented at length were eyewitness accounts by such highly placed individuals as Third Army Commander Vehip Pasha, Governor Celal of Aleppo, and "Circassian Uncle" (Çerkez Amca) Hasan, the officer in charge of Armenian "resettlement" in Syria. ${ }^{4}$

(4) The Archives of the Patriarchate of Jerusalem are the only known repository of the documents and trial files of the Commission for the Investigation of Evil Acts (Tedkik-i Seyyiat Komisyonu), ${ }^{5}$ along with the Military Tribunals (Divan-1 Harb-i Örfi). Armenians employed by the Military Tribunals during the armistice years made handwritten copies of these documents, the originals of which are missing. Even though the documents in Patriarchate archive are handwritten copies, they are very valuable and can be considered first-hand sources, since we can verify their authenticity. ${ }^{6}$

(5) The Minutes of the Fifth Department's (Beşinci Şube) Inquiry Commission, established in November 1918 by the Ottoman Chamber of Deputies (Meclis-i Mebusani) to investigate the allegations against government officials during the war years. ${ }^{7}$

(6) Minutes of the Ottoman Parliament during November and December 1918, when the Armenian deportation and murders were the subject of intense debate in the Senate (Meclis-i Ayan) and the Chamber of Deputies.

(7) Memoirs and certain diaries, including those published soon after the event. There may be memoirs yet to be published.

It is not an exaggeration to say that there exists a double standard among historians on the assessment of these documents. Just as with the Armenian Genocide itself, two factions have formed around different assessments of the abovelisted Ottoman materials. Those who defend the "official Turkish thesis," which considers the events of 1915 unexpected consequences of the relocation during the war years, rely exclusively on the Ottoman documents in the Prime Ministerial Archive (Başbakanlık Arşivi) as the only trustworthy source. This faction not only distrusts the US, British, German, and Austrian documents as politically motivated distortions of the events but also considers the documents presented in points (2) through (7) above unreliable. Most Western scholars, meanwhile, maintain that only the Western archives are reliable, while the Ottoman archival materials in the Başbakanlık Arşivi have been sanitized in order to cover up the genocide and are thus unreliable. These scholars have used the materials presented in points (2) to (7) extensively to corroborate the thesis of genocide.

My central argument in this article is that there is no major contradiction either between different Ottoman materials or between Ottoman and foreign 
archival materials. It is therefore erroneous to assume that the Ottoman documents (the term refers here mostly to documents from the Prime Ministerial Archive) were created solely in order to obscure the actions of the Ottoman government. In fact, as I will show in a further article intended for this journal, they contain information that runs completely counter to the official Turkish thesis, elucidating the intent of Ottoman authorities and how the genocide was organized. Ottoman archival materials support and corroborate the narrative of the Armenian Genocide as shown in the Western archival sources. We should therefore change our selective approach to the Ottoman materials, which is based on the belief that they are trustworthy only when they confirm our positions, and begin to consider the archival materials as a whole.

\section{The Matter of the Destruction of Documents}

The following statement was published in the 7 November 1918 issue of the daily newspaper Sabah: "Despite being researched by the government," documents relaying information about the "Armenian massacre have not been found"; before abandoning his office, "it is probable that Talât Pasha and the officers under his command had burned all documentation of the general directives regarding the massacres." 8 The news was accurate.

The reliable sources cited below indicate that some of the documents from that era were stolen or destroyed. The most explicit of this information can be pulled from the indictment of what has come to be called the "Main Trial," which is the action brought against the directors of the CUP in the Istanbul Military Tribunal. The prosecutor's office stated that three separate groups of documents had been either destroyed or "purloined." The first group consisted of documents of the "Special Organization" (Teşkilat-ı Mahsusa), which were nowhere to be found. In the indictment, the words of the prosecution are as follows: "Investigation of what had occurred reveals that important documents pertaining to this office (Tesskilat-1 Mahsusa)...have been purloined." "9

The second group consists of documents belonging to the Central Committee of the CUP. The prosecution's indictment states that, again, "all of the documents and ledgers of the Central Committee have been purloined." Thus, in various hearings led by the prosecution, witnesses Midhat Şükrü, K. Talât, and Ziya Gökalp would all testify that the documents of the CUP had been taken by Central Committee member Dr. Nazım. From those hearings:

Judge: The Union and Progress Party, which was transformed into the Reformation Group [Teceddüd Furkasi] at the direction of the Central Committee, were the official registers and other ledgers belonging to the Central Administration transferred to the Reformation Group ${ }^{10}$

Midhat Şükrü Bey: Of course, sir. However, later I heard that unfortunately Dr. Nazım Bey had taken them. I learned that from conversations with other officials. Judge: Was that investigated by the Reformation Group?

Midhat Şükrü Bey: No, sir. At the formation of the Reformation Group, your humble servant was questioned; I was called before the Central Committee and questioned about a document. Based upon the testimony of a Records official, it was learned that the entire document had been taken by Dr. Nazım Bey. ${ }^{11}$

Another Central Committee member, Ziya Gökalp, was to give similar testimony:

Judge: It is being said that important documents such as these were removed by Dr. Nazım Bey. Is that true? 
Ziya Gökalp Bey: Your humble servant heard from the office of the general secretary that Dr. Nazım Bey asked for the documents related to the society's history. He had reportedly said that he'd brought them from Europe and that he was taking them for safekeeping. The office said, "Fine, then take them." I heard this afterwards from Midhat Şükrü Bey. However, even later, when I was in prison, I found out that they had removed the other documents. Apparently, it turns out he'd taken all of the documents in a trunk. I learned that later. ${ }^{12}$

The third group is composed of certain documents from the Ministry of the Interior (Dahiliye Nezareti). In order to understand this category, one need only look at the indictment: "Aziz Bey, former Director of General Security, revealed with solid evidence and testimony that was laid out in a memo from the esteemed Ministry of the Interior that important reports and information taken from the office by Talât Bey prior to his resignation were not returned afterwards."13 Thus, many memoirs of the era recite an incident in which Talât Pasha, prior to escaping out of the country, had gone "to the shores of Arnavutköy, to the home of a friend... with a suitcase full of documents" and "proceeded to burn them in the furnace on the first floor of the house."14

Removal of documents was not confined to the Unionists; many documents were taken out of the country by German officers. Despite promising that he "wouldn't take any documents" with him when returning to Germany, Hans F.L. Von Seeckt, president of the Ottoman General Staff during the war years, did exactly that. On 6 November 1918, Sadrazam Izzet Pasha made a vocal protest concerning the removal of documents, and Berlin responded with promises to return the records, but nothing was returned. ${ }^{15}$

It is also important to note that the removal and destruction of documents did not occur solely during the post-war period. Directives sent by the CUP leaders by telegram were ordered to be destroyed. In a telegram dated 22 June 1915, bearing Talât Pasha's signature but issued by the Office of General Security, sent to all of the regional and governor's offices, instructions are given on how to behave toward those who, in the process of being expelled, converted to Islam. After this message the telegram includes the "demand that the copies of this telegram be seized from the telegraph office and destroyed after this notice has been confidentially communicated to those necessary."16

There are other sources of information that tell us that the directives sent to the regional offices were ordered destroyed. For example, the indictment mentioned earlier, for the trial of the directors of the CUP, states that the telegram sent to the governor of Der Zor, Ali Suat, was ordered to be destroyed after it was read. ${ }^{17}$ In another case, during the third hearing for the Yozgat trial, on 10 February 1919, the judge read out the statement given by the witness, Kemal, mayor of Boğazlayan, before the investigating committee during the course of his arrest. The statement established that the telegrams sent to Kemal had been ordered destroyed after being read. ${ }^{18}$ In the hearing on $24 \mathrm{March}$, the judge reminded Kemal of his statement "before the Commission for the Investigation of Evil Acts [Tedkik-i Seyyiat Komisyonu] that some of the documents related to the deportation had been ordered to be destroyed after they were read."19

One other piece of evidence that the directives containing orders to annihilate Armenians were ordered destroyed comes from Ahmet Esat (known today by the name Esat Uras), director of the Second Precinct of the Office of General Security. Esat, who was arrested by the British authorities, gave a statement that the many directives regarding annihilation of the Armenians had been sent out to the regional governors 
by couriers who had been ordered to read the messages and then return with the originals, which were to be destroyed upon return. ${ }^{20}$ This information would be confirmed by similar testimony from Yozgat Governor Cemal. In his written statement to the aforementioned commission on 12 December 1918, Cemal reported that "Necati Bey (Secretary to the Union and Progress party for the region) came to Yozgat... [H]e executed the letter, signed by Governor Atif Bey, which he held in the palm of his hand...I demanded the letter in question from the aforementioned Necati Bey but he wouldn't give it." ${ }^{21}$ This statement would be confirmed by similar testimony by Governor Cemal at the eleventh hearing in the Yozgat trial on 5 March 1919. Cemal stated that Party Secretary Necati showed him an order for the annihilation of the Armenians and that, upon his request, Necati refused to hand over the paper; he only showed it. This was also the written statement of Cemal to the aforementioned commission. $^{22}$

\section{The Destruction Continues after the War}

Once it became clear that the war would end in defeat, the process of destroying documents continued unabated. For example, the following testimony is taken from the Istanbul Military Tribunal hearing that took place on 3 June 1919 for the trial against members of the cabinet. The witness is the former minister of postal services, Hüseyin Haşim, and he is testifying as to how the documents from the War Ministry were destroyed:

Judge: As was understood from the testimony given by the officials from Çatalca, in their defense regarding the issuance of a directive to burn and destroy all communications by telegraph, do you have any recollection as to why this directive was issued?

Hâşim Bey: I cannot remember anything, although there was in fact a notice from Headquarters about the prevention of military communications falling into the hands of the enemy. It was done in furtherance of that no doubt. In fact some of the telegrams weren't burned but were shredded and sold. It occurred two to three days before your humble servant was working at the ministry. The ministry was dispatching accounting department officials to the Military Tribunal and demanding that they be burned. It's likely that it's related to that business. Your humble servant doesn't recall.

Judge: Sir, it was related only to military communications?

Hâşim Bey: Yes sir, it had to do with military communication and nothing else. Military communication along with communications with headquarters. ${ }^{23}$

The individual referred to by the judge, the former deputy director of the Çatalca Postal and Telegraph Office, Osman Nuri Efendi, would be prosecuted for burning documents. His trial began on 4 August 1919. The defendant testified that "I was following orders when I burned some documents. Under the authority of my supervisors I was to burn certain documents from one year to another and I did." We know that these documents related to military matters. [It is unknown what the final judgment was.] ${ }^{24}$

After the defeat in war, the burning of documents continued during the armistice period. Upon the resignation of the cabinet of Talât Pasha, the new cabinet under Ahmet Izzet Pasha was formed on 14 October 1918. Izzet Pasha took on the role of minister of war. The first action the Pasha took was "to order the Teşkilat-ı Mahsusa [Special Organization, otherwise known as the 'Eastern Bureau' within the Ministry of War at the time] to stop all activities, destroy their archival records ...."25 Ahmet Esat, director of the Second Precinct of the Interior Ministry, gave similar testimony to the 
British: "Just before the treaty to lay down our weapons, the staff went into the archives at night and cleaned out most of the records." 26

Nor were documents destroyed only in Istanbul during the armistice period. Orders were sent out to the regional offices to destroy the documents in their possession. Refik Halid Karay was the general director of the Postal-Telegraph Office during that time. When Karay's memoirs of the period were published in Aydede magazine in 1948, he received a lengthy letter from H. Sadik Durakan, a longtime employee of the Postal Telegraph and Telephone Office (PTT). Later, when Karay compiled his work into a book, the letter was published in full, unedited. Here is an excerpt:

I wish to recount to your honor, an event which I witnessed at that office during the armistice period. As you know, following the Mondros Armistice agreement, the armed forces of the Allied powers, coming in from all directions, began to capture and invade our land. During this invasion, thinking that the documents and communications which were in the possession of the PTT Central offices would be targeted, and in an attempt to prevent those documents from falling into the hands of the enemy, Mehmet Emin Bey, sending an official telegraphic notice to all of the offices, ordered that all official documents, copies of telegrams and their originals, which were in our possession, be completely destroyed. ${ }^{27}$

It is apparent that some of these telegrams fell into the hands of British forces. On 24 October 1919, a telegram sent by the Ministry of the Interior to the Antep regional office was in fact intercepted by the British. The telegram orders that all original telegraphic messages sent to the region since the mobilization for war began be destroyed. ${ }^{28}$ On 17 June 1919, the then minister of foreign affairs, Safa Bey, while protesting the interception of communications in the presence of the British High Command, admitted that a notice had been sent to the towns and townships of the telegraph office of Diyarbekir to destroy all original documents received by them between 1914 and $1918 .^{29}$

Despite the fact that there was a systematic effort to cleanse certain documents from the archive, no matter how thorough the effort may have been, a complete purging of any trace of Ottoman policies toward its non-Muslim populations was nearly impossible to achieve. While destroying all the records of the CUP, for example, might be feasible, doing the same for all the communications that went back and forth between the Ministry of the Interior and all the regional offices is another thing altogether. A memo sent to one office was not registered only there but was disseminated to other offices so often that the probability of its appearance elsewhere is extremely high.

Although annihilation of the Armenians came onto the agenda as a party policy, deportation was taken up as a state policy, and the entire state mechanism was put into play in order to execute that policy. As a result, hundreds and thousands of written communications were sent between state offices, between the smallest towns and villages and their regional offices, and between those regional offices and the highest political decision-making bodies. It would be impossible to destroy all that documentation.

\section{Measures against Armenians Were Part of a General Population Policy}

The available documents from the seven sources listed above lead inexorably to a single conclusion. ${ }^{30}$ Before World War I, the CUP formulated a policy that they began to execute in the Aegean region against the Greeks and, during the war years, 
expanded to include the Assyrians, the Chaldeans, the Syrians, and especially the Armenians, a policy that eventually became genocidal. The main goal of this policy was, in the CUP's own words, "liquidating the concentrations of non-Turkish population that had accumulated at strategic points, and which were susceptible to negative foreign influences." 31 The origin of this plan (or plans), which I call "the homogenization of Anatolia," can be traced to the conclusion of the Balkan Wars.

The concrete preparation of these plans, according to the memoirs of many leading figures, such as member of the "Special Organization" (Teşkilat-ı Mahsusa) Kuşçubaşı Eşref, leading Unionist leader Halil Menteşe, ${ }^{32}$ and CUP Izmir Secretary Celal Bayar (later third state president of Turkey), was made at the beginning of 1914 and especially with the appointment of Enver Pasha to the Ministry of War in January 1914. Kuşçubaşı Eşref mentions a meeting with Enver Pasha in the Ministry of War on 23 February 1914, ${ }^{33}$ during which Enver laid out some thoughts about the importance of getting rid of non-Muslims because "the non-Muslims had proven that they did not support the continued existence of the state. The salvation of the Ottoman State would be linked to stern measures against them." In the words of Kuşçubaşı Eşref, the non-Muslims were "an internal tumor" whose "purging" was a "matter of national importance." ${ }^{34}$ In Kuşçbaşı's words, "the first task was to separate the loyal from the traitors." 35 Halil Menteşe states in his memoirs that "Talât Pasha made the removal of all traitorous sources from the nation a top priority." 36

For this purpose, according to Kuşçubaşı, the newly established Teşkilat-1 Mahsusa devised a broad plan to eliminate the long-existing burden posed by dangers from within the Christian communities of the Empire. ${ }^{37}$ Detailed reports were prepared outlining the elimination of the Christian population. These measures were implemented in the Aegean region in the spring of $1914 .^{38}$

As in the case of the Armenian Genocide, the first measures against the Greeks on the Aegean coast followed a two-track communication and operation system. On the one hand, the Special Organization carried out the illegal operations, including the "services which the forces of the government and public organizations could never hope to perform." 39 On the other hand, the government had official population exchange agreements with Greece and Bulgaria, according to which Muslims and Christians should be exchanged and resettled in their respective villages.

With the beginning of 1913, the Ottoman government, in separate treaties with Bulgaria and Greece, had agreed to the exchange of ethnic populations across national borders. The dozens of communiqués that appear in the records of the Ministry of Interior's Office of Tribal and Refugee Settlement (hereinafter known as the IAMM) ${ }^{40}$ prove that the resettlement of Muslim immigrants was organized in a systematic way without waiting for final agreements with the respective governments in the Balkans. In a telegram sent from the office of the IAMM to the province of Aydin, for example, it is ordered that "even though we, upon the proposal of Venizelos, agreed to exchange the Greek population in the Province of Aydın with the Muslim population in Macedonia," since it will take a long time to establish a commission to deal with the details of the population exchange, it is advised to resettle the Muslims who have been arriving step by step in the Greek villages. ${ }^{41}$ This document makes it clear that measures were taken in a systematic way to settle Muslims in the villages of Western Anatolia that had been emptied of their Greek inhabitants:

Information is needed as to which villages and towns from the region, the number of residences and the number of Greeks who emigrated from them thus far, along with the names of these villages and towns and number of residences and the property that was 
left behind, the general and specific agricultural pursuits they pursued, their industrial and agricultural trades, in type and kind and following their emigration, if there have been refugees who have resettled in their place, whether or not they intend to stay. ${ }^{42}$

As much as the writers of these communications use the expression "liquidation of non-Turkish elements," the real target to be purged was non-Muslims. Coded telegrams issuing from the Ministry of the Interior made it clear that non-Turkish Muslims who needed to be resettled were to be "assimilated." For example, a telegram sent by Talât Pasha to Diyarbekir on 2 May 1916, after making it clear that the Kurds, who would continue to maintain their identity in the region, should not be settled in the areas of Urfa and Zor, states that priority should be given to ensuring that "they [Kurds] should not be permitted to continue their tribal existence nor ethnic identity." ${ }^{43}$ Similarly, on 4 May 1916, a coded telegram to the governors' offices in Urfa, Marash, and Antep urged that the Kurdish refugees be "discouraged from living communally" and that everything be done to ensure that "they abandon use of their language and customs." 44

It is helpful to think of this plan to create a new state composed primarily of Turks as having two main goals. The first aim of the plan was to remove all non-Muslims, regarded as a serious threat to the state, from Anatolia. The second aim was to make changes in the structure of the population so that non-Turkish Muslims could more easily be assimilated into the greater body of society.

These policies, which were put into force during the period between 1913 and 1917, resulted in a complete change in the ethnic makeup of Anatolia. ${ }^{45}$ The estimated 17.5 million people who lived in Anatolia at the time were so uprooted that at the end of this period, at least one-third of them had been either resettled somewhere else, deported, or annihilated.

It is important that a clarification be made here in order to avoid confusion or misinformation. What is not being claimed is that the deportation or resettlement of the entire Anatolian population between 1913 and 1917 was the result of a preconceived comprehensive plan. The coded communications of the Ministry of the Interior of that period, in particular, point to forty-four different reasons for the movement in population, among them the following:

(1) For the Greeks in the Aegean region and the Armenians in general, all of whom were perceived as threats to the nation, forced deportation was the main tactic of choice. This took the form of threats, looting of businesses and homes, limited cases of murders, and forced deportation to Greece; the Armenians were more often subjected to killings en route to settlements elsewhere or were left for dead on the road, deserted in remote locations.

(2) (a) The deportations and forced emigration of Christian citizens were justified on the basis of military objectives; as an example, one can look at the forced emigrations of Nestorians and Assyrians from the Van region at the end of 1914, while the same tactic was used against the Greeks of Ayvalik and the Black Sea shore. The first deportations of Armenians that took place between February and April of 1915 from the Çukurova region would fit into this category also.

(b) Some Arab families were deported for political reasons. The deportation of 
Arab families and important individuals from Syria by Cemal Pasha fits into this category.

(3) The settlement of Muslims who had escaped from the war zones into the regions in the interior was necessitated by the resettlement policies.

There developed a planned policy of resettling the areas that had been emptied of Armenians with Muslims who had come from the Balkans and Caucasus regions at different times and were settled mainly in Western Anatolia.

It is undeniable that there were plenty of instances in which the categories overlapped. For example, in September 1914, from the areas closest to Iran, "the Nestorians who were ripe for provocation from outside" were settled into Ankara and Konya. In order to prevent them from creating a community in their new locations, they were settled in Muslim-dominated areas with strict orders that their settlements must not exceed twenty residences in number. ${ }^{46}$ When, as a result of war conditions and the Russian advance, some Kurds were to leave their places, despite the movement not being planned in advance, they had to be resettled to the interior regions. In their resettlement special attention was paid to keeping them from being too numerous in any of the newly settled locations. A telegram from the Ministry of the Interior demands that attention be paid to "ensuring that the Kurdish refugees who have been moved from the war zones be kept apart from their leaders, Imams and Sheiks, and that they not exceed $5 \%$ of the local populations in the interior of Anatolia where they have been dispatched." 47

It is extremely important to observe the parallels in organization and staff between the forced emigration of Greeks, which began in the summer of 1914 in Western Anatolia, and the equivalent action of Armenian cleansing from Eastern Anatolia during the war years. Dozens of examples of similarities were documented and reported by US Ambassador Henry Morgenthau and Arnold Toynbee, a British diplomat, from the way the state kept itself in the background while the dirty work was performed by the Special Organization (Teşkilat-1 Mahsusa) to the fact that people were forced to emigrate under threats of terrorism and murder and the formation of labor battalions by gun-wielding youths. ${ }^{48}$

\section{The Decision That Followed Extensive Debate}

As the above summary indicates, the decision to deport Armenians did not arise as an objective of war but was a part of a larger plan. That decision was also based on a deeper issue, known as the "Eastern Question," and aimed to put an end to the fragmentation of the Ottoman Empire. As one element of a larger problem, the Armenian Reform Agreement signed with Russia in February 1914 for reforms in the eastern provinces can be viewed as the catalyst for a decision that the Armenians constituted a serious threat to the existence of the Ottoman state. The most important document to reveal the true intent underlying the decision for the deportation of the Armenians is an official statement issued by the Ministry of the Interior on 26 May 1915 and sent to the office of the Grand Vizier. This document states that deportation of the Armenians needs to be undertaken so that the Armenian question can be "brought to an end in a manner that is comprehensive and absolute [esâslı bir suretde hal ve faslı ile külliyen izâlesi]." Although this document has been mentioned in various publications on the subject, the complete text has not appeared in modern studies, except for an extensive summary in one of them. ${ }^{49}$ 
This document was published in its entirety in the newspaper Ati during the armistice period $^{50}$ and explains the reasoning behind the deportation decision from a historical perspective:

[A] reform that was entirely related to Ottoman internal affairs turned into an international issue, wherein by some regions of the Empire coming under the influence of foreigners certain privileges and special administrative organizational regulations were demanded. As a matter of fact, it became bitterly clear that this reform and reorganization, made under duress and foreign influence, caused the fragmentation of the Ottoman nation. This problem, for which a real solution has been sought... [as a result of various Armenian actions he describes], the state, by necessity, after consultation with local officials and the military commanders, started... an action believed to be completely within the interest of the state, begun necessarily according to proper rules and procedures.... 51

One sentence that carries enormous weight in this passage is the following: "While the preparations and presentations have been proposed and considered for a final end, in a manner that is comprehensive and absolute, to this issue constituting an important matter in the list of vital issues for the State." 52 Talât Pasha made similar remarks to Henry Morgenthau. In his memoirs, Morgenthau comments as follows on a meeting he had with Talât on 9 July 1915: "Talaat said that they had discussed the matter very thoroughly and arrived at a decision to which they would adhere. When I said they would be condemned by the world, he said they would know how to defend themselves; in other words, he does not give a damn." 53

The fact that the decision about the Armenians was made after a great deal of thought, based on extensive debate and discussion by the Central Committee of the CUP, can be understood by looking at other sources of information as well. The indictment of the Main Trial states as follows: "The murder and annihilation of the Armenians was a decision taken by the Central Committee of the Union and Progress Party." These decisions were the result of "long and extensive discussions." In the indictment are the statements of Dr. Nazım to the effect that "it was a matter taken by the Central Committee after thinking through all sides of the issue" and that it was "an attempt to reach a final solution to the Eastern Question."54

In his memoirs, which were published in the newspaper Vakit, Celal, the governor of Aleppo, describes the same words being spoken to him by a deputy of the Ottoman Parliament from Konya, coming as a "greeting of a member of the Central Committee." This deputy told Celal that if he had "expressed an opinion that opposed the point of view of the others, [he would] have been expelled." 55

That the decision regarding deportation went beyond temporary military expediency and was instead intended to resolve the "Eastern Question" forever can be seen in a letter written by Bahaeddin Şakir, published by Ahmet Emin Yalman in his memoirs. ${ }^{56}$ In his work, Yalman introduces Bahaeddin Şakir as a supporter and defender of the policy of "complete annihilation" of the Armenians. Şakir's letter reads, "It is understood that the presence of Armenians, living as they do straddling the Russian border, constitutes a major danger to the future of our nation. Our nation's salvation depends on doing whatever is necessary to remove this danger." adds that the purpose of the policy was understood by "some politicians" to be necessary for the "annihilation of the Armenians in order to create a racially homogeneous Anatolia."58 


\section{The Aim of the Deportation Was the Annihilation of the Armenians}

Many of the documents that came out during the trials state that the purpose behind the deportation was the annihilation of the Armenians. The indictment of the Main Trial refers to many documents that touch on this subject. Among these, the testimony of Ihsan Bey, director of special letters of the Ministry of the Interior, is a good example. While Ihsan Bey was mayor of Kilis, Abdu'lahad Nuri, who had been sent from Istanbul to Aleppo, relayed to him that the deportation was being executed for the actual purpose of annihilating the Armenians. Nuri tried to convince Ihsan Bey of the wisdom of the policy by stating that "I was with Talât Bey and was given the orders about annihilation from him personally. The salvation of the nation is dependent on it." 59

Vehip Pasha, who had been appointed commander of the Third Army in February 1916, gave this written statement in December 1918 to the Commission for the Investigation of Evil Acts (Tekdid-i Seyyiat Komisyonu), which had been assigned the job of investigating the Armenian deportations and killings: "The massacre and annihilation of Armenians and the looting and plunder perpetrated by their murderers was decided and envisioned by the Central Committee of the Union and Progress Party." According to Vehip Pasha, "A program that had been pre-ordained and executed under an absolute and clear intention for atrocities, firstly by the delegates of the Central Committee of Union and Progress and secondly, pushing the law and conscience aside, using the leaders of the state like tools for the furtherance of the wishes and intentions of that party, having their orders and judgments and persecutions performed." 60 The Pasha added that the fact that government officers, despite seeing and hearing of the crimes committed, did nothing to stop them and, in fact, often aided and abetted the crimes shows without a doubt that the actions were planned. ${ }^{61}$

Vehip Pasha's assertion that there was direct involvement of state officials can also be corroborated. Many governors and mayors who steadfastly tried to limit their actions to deportation alone were relieved of their duties or, worse, killed. One particular piece of evidence that the actual aim was the killing of Armenians relates to an incident witnessed by the Trabzon representative of the CUP, Hazlf Mehmet Emin, wherein Armenians were loaded onto boats and drowned at sea. During a session of the Ottoman Assembly on 11 December 1918, when the incident was being debated, Mehmet Emin Bey, considered an ardent Unionist, commented on the record, "[y]our humble servant saw this incident, I mean, I saw an actual Armenian incident." He then added, "There was a mayor in the Ordu district [a city on the Black Sea]. He loaded up a boat with Armenians on the excuse that he was sending them to Samsun and then proceeded to dump them into the sea. I heard that governor Cemal Azmi did the same thing.... As soon as I got here [Istanbul], I relayed what I'd witnessed to the Ministry of the Interior ... But I couldn't get anything done about the governor. I tried for about three years but nothing. They said it was this, it was that, it was war; in short, nothing came of it."62

What is understood from the dozens of transcribed telegrams issued by Talât Pasha documented in the indictment of the Main Trial is not that he wanted state officials to prevent the killings or to initiate investigations but that he wanted all the dead, the casualties of the policy, who were lining the roadways to be taken away. In the telegrams he makes clear that anyone not following his orders to have the corpses cleared from the roads would be punished. For example, a coded telegram sent on 21 July 1915 to the governor's offices of Mamuretulaziz, Urfa, and Zor 
demands "the removal of the dead in the streets, with care taken that they are not thrown into streams, lakes or rivers, and that their possessions left behind in the streets be burned." Again, a coded telegram from the governor of Mamuretulaziz to the governor's office of Malatya states that "despite the urgency of the notice, the presence of so many dead in the streets" is being brought to the attention of officials in Malatya and threatens "the harshest of punishments to all officials who express any distress over this fact will be reported by office of the Ministry of the Interior."63

We have other direct evidence to show that the decision to deport Armenians was ultimately meant to lead to annihilation. A telegram dated 21 June 1915, sent by Bahaeddin Şakir, member of the Central Committee of the CUP, to the party secretary of Harput, Resneli Nazım, which was published in the indictment of the Main Trial, contains the following statement: "Are the Armenians who have been sent from there being liquidated? Are the troublemakers you told us you had expelled being exterminated, or are they just being expelled?"64 This telegram was not only used in the indictment of the Main Trial but played an important role in the Mamuretulaziz and the party secretaries' trials as well.

Similar examples of telegrams were read into the record during the Yozgat trial, which started on 5 February 1919. By the ninth hearing (22 February 1919), twelve telegrams had been read in court that contained statements related to deportation, annihilation, and massacres. For example, in a telegram dated 5 August 1915 sent by the Boğazliyan detachment commander, Mustafa, to 5th Army Corps Deputy Commander Halil Recayi is the statement that a group of "troublemaker Armenians obtained from town and by chance" were "sent to their destinations." ${ }^{65}$ Halil Recayi's response of the same date asks for an explanation of what the term "sent to their destinations" means. ${ }^{66}$ The gendarmerie commander answered the same day with "Since the aforementioned Armenians were troublemakers...they were killed."67 From the same trial, a different telegram, this one from Boğazliyan Gendarmerie Commander Hulusiye, uses similar language, stating, "sent out' means they were exterminated."68

One comes across many reports from German officers, as well as from the German embassy and consulates, documenting their belief that the Unionist leaders' plan for deportation had as its ultimate purpose the annihilation of all Armenians. ${ }^{69}$ One of the most damning pieces of evidence is a statement by Talât Pasha recounted by the head of the Armenian desk at the German embassy in Istanbul, Dr. Holleg Mordtmann. In a telegram, Mordtmann states that Talât Pasha had told him, concerning the deportation, that "the subject of it was the annihilation of the Armenians." 70 Additionally, a "confidential" report dated 23 August 1915, sent by one Colonel Stange, a German officer, to the embassy in Istanbul, is of utmost relevance. Stange, who had worked with Bahaeddin Şakir in 1914-1915 in the Teşkilat-1 Mahsusa (Special Organization), reports that based on his observations, the deportation and murder of Armenians was not being done for reasons related to war or to the military; the deportation, which so often relied on taking advantage of certain circumstances, was the realization of a "plan that had been thought out over many years." Stange further states that the "deportation and annihilation was a decision taken by the "Young Turks' committee in Istanbul" and that Bahaeddin Şakir was coordinating it from Erzurum. ${ }^{71}$ 


\section{How Were the Deportation and Massacres Organized?}

There is no need to discuss in detail the process by which the final decision for annihilation of the Armenians came about, as this topic has been covered elsewhere. ${ }^{72}$ However, the matter can be linked to the defeats of the Teşkilat-1 Mahsusa in the Caucusus and Lake Van regions and to the defeat of the Ottoman army by the Russians at Sarıkamış in January 1915. Bahaeddin Şakir, who had lived through this experience and had barely escaped death, was "of the opinion" that as a result of "the behavior which the Armenians had exhibited towards Turkey and the support which they extended to the Russian army ... one needed to fear the enemy within as much as the enemy beyond."73 Şakir, who had obtained documents related to the activities of Armenian gangs in the region, traveled to Istanbul near the end of February 1915 and tried to convince his friends in Istanbul that the country had to rid itself of this threat. ${ }^{74}$

There is a very high probability that the decision to exterminate was made during the debates that took place in Istanbul near the end of March. At the conclusion of these discussions, "it was decided that Dr. Bahaeddin Şakir Bey should turn away from the Teşkilat-1 Mahsusa's work that focused on foreign enemies and start dealing with the enemies who are within."75 In other words, Şakir had been assigned the task of dealing with the "internal Armenians." Arif Cemil commented that "the end result of all this discussion and debate was that the promulgation of deportation had been turned into law" and that "when Dr. Bahaeddin Şakir Bey returned to the Caucasian front, the new agenda completely took over." "In fact, based on a telegram sent by Talât Pasha on 5 April 1915 from the Special Letters Office of the Ministry of the Interior, which states that "Bahaeddin Şakir Bey will be returning soon and special appropriations will be sent for the refugees," one can conclude that the decision regarding deportation was made sometime between the end of March and the beginning of April. ${ }^{77}$

According to the documents we have, the deportation orders for the complete and fundamental elimination of this concern were sent to the regions by the Ministry of the Interior sometime around the end of April or the beginning of May. ${ }^{78}$ The earliest document available is a telegram dated 24 April 1915 and sent to Cemal Pasha, ordering that the Armenians who had already been sent to Konya from the Zeytun and Marash regions be further dispatched in the direction of Aleppo, Urfa, and Zor. ${ }^{79}$ Another telegram was sent to some of the regions on 26 April 1915. This telegram stated that the Armenians who are to be sent out of "Zeytun and Marash, Iskenderun, Dörtyol, and Haçin" were to be "sent to the "southeast and Zor and Urfa districts." 80 Another coded telegram sent to the governor's office of Marash on 3 May 1915 ordered the Armenians of Zeytun to be "completely expelled." 81

Following these telegrams, Talât Pasha began to send telegrams requesting the numbers of Armenians who had been expelled and settled elsewhere. For example, a telegram dated 5 May 1915 was sent to Aleppo, seeking information as to where the Armenians who had been moved there could be settled. ${ }^{82}$ Another was sent to Adana, asking, "How many Armenians have been expelled from Haçin, Dörtyol, and other localities since 7 May 1915, and where have they been sent?"83

When news of an uprising in Van reached Istanbul, the Ministry of the Interior followed up with a coded telegram to the Van and Bitlis regional offices, dated 9 May 1915, stating that the Armenians in the region of Van were to be deported and that the action must "be handled personally." The telegram states that the deportation will 
encompass Bitlis, the south of Erzurum, Mush, and the areas around Sasun and that a similar telegram has been sent to Erzurum. ${ }^{84}$

Based on the coded telegram from Talât Pasha on 5 April 1915, eyewitness accounts, and the reports from German consular offices, it is possible to conclude that the purging of Armenians from Erzurum and its surrounding villages started in the second half of April. In his memoirs, Ragip Bey, a high-ranking Ottoman bureaucrat, after explaining that he arrived in Erzurum on 14 April 1915 and left on 26 April, states that, "as a result of the Armenian deportations, the poor Armenian girls and women in the area were in the most deplorable, wretched and miserable state. Our hearts were quite wounded at the sight." ${ }^{85}$ According to reports issued by the German consulate, the emptying-out of the villages surrounding Erzurum had started in early May: "by May 15th, all of the villages... had been emptied out." 86

It is probable that during March and April of that year, the CUP's Central Committee had taken two parallel decisions: one for deportation by the Ministry of the Interior, the second for extermination. The Ministry of the Interior was in charge of sending out the orders regarding deportation by way of its official lines of communication to the governors. In contrast, the order to exterminate was disseminated through the Katib-i Mesuller (Responsible Secretaries). The annihilation was actually executed with the help of the Ministry of the Interior's gendarmerie and the CUP's Teşkilat-ı Mahsusa (Special Organization) gangs.

The most revealing statement in support of the argument that the decisions taken in March and April 1915 were on parallel lines comes from Reşit Akif Pasha. When Talât Pasha resigned in October 1918, and the first government of the armistice period was formed under Ahmet Izzet Pasha, Reşit Akif Pasha was appointed president of the Council of State. He gave a very important speech before the newly formed Assembly on 12 November 1918. According to Reşit Akif Pasha, the Armenian genocide began with a secret order for deportation that was issued by the Ministry of the Interior to all regional offices:

While humbly occupying my last post in the Cabinet, which barely lasted 25 to 30 days, I became cognizant of some secrets. I came across something strange in this respect. It was this official order for deportation, issued by the notorious Interior Ministry and relayed to the provinces. However, following [the issuance of] this official order, the Central Committee [of Union and Progress] undertook to send an ominous circular order to all points [in the provinces], urging the expediting of the execution of the accursed mission of the brigands. Thereupon, the brigands proceeded to act and the atrocious massacres were the result. ${ }^{87}$

This speech was defined by many of the newspapers as "extremely remarkable and noteworthy," and it was published "in full for its special importance."88

The information given by Reşit Akif Pasha was repeated by Vehip Pasha. In the written statement noted above, Vehip Pasha relates how, based on the statements of witnesses whom he had interrogated himself, the official orders were distributed by way of the governors' offices, while the orders related to the annihilation were organized by Bahaeddin Şakir. Vehip Pasha began an investigation of the crimes and arrested the gendarmerie officers and their assistants whom he suspected. These persons told Vehip Pasha that "Memduh Bey, from the governor's office of Erzincan, had given the order to take action this way, while those who had been directly involved in the deplorable acts had taken their direct orders from Dr. Bahaeddin Şakir Bey." 89 
The mechanism operated in the following way: the official deportation command moved from the Ministry of the Interior's channels of communication to the governors, who then transferred the orders down to the gendarmerie of the security branch of the Ministry of the Interior. Meanwhile, the attack and annihilation of the caravans of people were organized by the Central Committee through Bahaeddin Şakir. The most important service provided was by the Katib-i Mesuller, whose job it was to distribute the coded orders to all regions.

\section{The Role of the Katib-i Mesuller and Bahaeddin Şakir}

The responsible party secretaries (Katib-i Mesuller) played an extremely important role in the Armenian deportation and killings. With the general mobilization on 2 August 1914, the Katib-i Mesuller were responsible not only for establishing the units of the Teşkilat-1 Mahsusa but even for directing the actions of some of the gangs. Many telegrams read out during hearings of the Main Trial established their role in these actions. ${ }^{90}$ During the Main Trial, a statement in the second indictment brought against the cabinet members refers to the Katib-i Mesuller as acting like erkani Mahsusa ("special high officials") in the party and constituting a secret branch of the government. ${ }^{91}$ Because of the special role they played in the events being tried, their prosecution was separated from that of others, and a separate action was initiated against them. In the final court ruling for that trial, the Katib-i Mesuller were referred to as the "secondary criminals on the side, for the society's aforementioned criminal actions." 92

There is a great deal of evidence that the Katib-i Mesuller were responsible for disseminating the orders regarding the annihilation of the Armenians to the regions. For example, during the Main Trial, the presiding judge repeated that there was much evidence to show that the party's commands were disseminated to the regions by way of the secretaries and that there were many instances where governors did not obey the orders and were removed from office. Additionally, the judge questioned almost every witness with statements such as, "The responsible delegates went to Ankara, Kastomonu, Erzincan, Yozgat, Trabzon, Sivas and similar places, giving the governors and their offices sometimes confidential instructions. Were you aware of this?"93 The Ankara governor, Mazhar Bey; the governor of Kastamonu, Reşit Bey; and the governor of Yozgat, Cemal Bey, all repeated throughout their testimony in the hearings that they had been removed from their positions upon the application of the Katib-i Mesuller. ${ }^{4}$

In fact, these governors all gave testimony before both the Commission for the Investigation of Evil Acts and the hearings mentioned above to the effect that they had been removed from their positions for failure to obey orders. For example, Mazhar Bey, describing his particular situation, stated,

I pretended I didn't understand the order that was sent from the Ministry of the Interior for the deportation of the Armenians. As you know, while there were other provinces that had already completed the deportation, I had never even started it. Atif Bey came... he gave me the order to massacre and kill the Armenians, personally. And I said, "No, Atif Bey. I'm the governor, not a criminal. I can't do it. I'll get up from this chair and you come do it if you like."95

The story for the governor of Kastamonu, Reşit Bey, was the same. The court ruling against the Katib-i Mesuller indicates that because Reşit Bey had stated, "I won't paint my hands with blood," he had been removed from the governor's office upon the application of Katib-i Mesul Hasan Fehmi. ${ }^{96}$ 
The governor of Yozgat, Cemal Bey, gave a written statement to the Commission for the Investigation of Evil Acts on 12 December 1918 that contained similar information. In his statement he explained that Necati Bey, a Katib-i Mesul, had shown him an official written order demanding that the Armenians be annihilated; when Cemal asked for the written order, however, the Katib-i Mesul would not give it to him. Cemal further stated that he told Necati Bey that, "since you don't appear to have official authority, I can't at this juncture engage in a sinful act," thus refusing to obey the order. Within a few days Cemal was removed from office. ${ }^{97}$ At the eleventh hearing of the Yozgat trial on 11 March 1919, Cemal recounted how Necati Bey had told him that the order was in furtherance of the wishes of the Central Committee of the CUP. ${ }^{98}$

Not only did officials risk of being removed from office, there were mayors who were killed for failing to obey an order. The mayor of Lice, Hüseyin Nesimi, did not obey the order to massacre the Armenians. When he demanded that the order be given to him in writing, he was removed from office and later given orders to travel to Diyarbekir; he was killed on the way there. ${ }^{99}$ In his memoirs, the mayor's son, Abidin Nesimi, recounts that the removal of state officials was done at the behest of the governor of Diyarbekir, Dr. Reşit, and that there were others who were as unlucky. "Ferit, the governor of Basra, Bedi Nuri, the governor of Müntefak, Sabit, deputy mayor of Beşiri, [and] Ismail Mestan, the journalist," were among those who were killed. The reason for the murders was clear: "the removal of administrative staff who would oppose [the annihilation of Armenians] was inescapable. In furtherance of this...the removal of the individuals named was considered absolutely necessary." 100 The mayor of Midyat was also among the dead, "by order of the Governor of Diyarbakir, for resisting the command to murder the Christians living within his township."101 During the 11 May 1919 hearing of the Trabzon trial, Justice Department Inspector Kenan Bey remarked that he had gone to Samsun to conduct an investigation and, while there, "was a witness to an occurrence in the deportation ... [in which] the mayor of Bafra was killed."102

Along with the Katib-i Mesuller, Bahaeddin Şakir "traveled around the eastern provinces meeting with governors and others" in an effort to publicize the decision of the CUP's Central Committee. ${ }^{103}$ During the hearings of the Main Trial, the judge declared that Bahaeddin Şakir had become the commander of the body of all units constituting the Teşkilat-1 Mahsusa. ${ }^{104}$ Additionally, he would question witnesses as to whether they had knowledge of the fact that both Nail Bey (another Katib-i Mesul) and Bahaeddin Şakir had gone among some of the brigades of the towns in Trabzon province and given secret commands. ${ }^{105}$ During the 2 August 1919 hearing for the Mamüretülaziz trial, Erzurum Governor Tahsin testified that units of the Teşkilat-1 Mahsusa under Bahaeddin Şakir's control were responsible for the annihilation of the Armenians:

During the deportation of the Armenians I was in Erzurum ... The caravans which were subject to attacks and killings resulted from the actions of those who'd assembled under the name "Teş-1 Mahsusa." The Teşkilat-1 Mahsusa was composed of two units. When I came back from Erzurum, the Teşkilat-1 Mahsusa had turned into a major power and they'd become involved in the war. The Army knew about it. Then there was another Teşkilat-1 Mahsusa, and that one had Bahaeddin Şakir's signature on it. In other words, he was sending telegrams around as the head of the Teşkilat-1 Mahsusa... Bahaeddin Şakir had a code. He'd communicate with the Sublime Porte and with the Ministry of the Interior with it. During the deportation he communicated with the Army as 
well... Bahaeddin Şakir had two different codes with which to communicate with both the Sublime Porte and the Ministry of War. ${ }^{106}$

From the telegrams that he issued, which were used extensively to build prosecution cases during the hearings, one comes to an understanding that Bahaeddin Şakir was responsible for all actions that took place in the region. For example, in the following telegram, which was incorporated into the court ruling of the Mamüretülaziz case, Şakir asks the former governor of Antalya, Sabûr Sami Bey, "[s]ince there isn't a single Armenian left in the vicinity of Erzurum, Van, Bitlis, Diyar-i Bekir, Sivas, and Trabzon and they have all been sent to Mosul and Zor, what's been happening in Antalya?"107 Another example of such a telegram is the one from Şakir mentioned earlier, during the discussion of the Main Trial: "Are the troublemakers you told us you had expelled being exterminated, or are they just being expelled?"108

There is still other evidence to corroborate the fact that the Central Committee's decision to annihilate the Armenians was distributed by special couriers. After the armistice, Ahmet Esat, director of the Second Precinct of General Security, which was tied to the Ministry of the Interior, tried to sell to the British what he claimed were the minutes of a meeting having to do with the massacres of Armenians. He gave the British four separate documents, two of them in his own handwriting. According to the information he provided, messages were supposed to be disseminated to the various districts by couriers who were ordered to read them aloud and then return with the originals, which were to be destroyed. ${ }^{109}$

\section{Some Orders for Annihilation Were Sent by Telegram}

There were instances in which the orders to annihilate had to be sent by telegram. The final court ruling of the Bayburt trial confirms that the decision to annihilate was sent by the Central Committee to the regions by way of special couriers. The ruling also includes the statement of Nusret, who was convicted and executed as a result of this trial. Nusret's statement declared that he had received a confidential order from Istanbul stating that not a single Armenian was to be left alive and that those who did not obey this order would be executed. ${ }^{110}$

Evidence clearly shows that the orders sent by telegram were to be destroyed immediately after they were read. For example, the indictment of the Main Trial recounts that the governor of Der Zor, Ali Suat, was told to destroy a telegram after it had been read. ${ }^{111}$ For another example, during the third hearing of the Yozgat trial on 10 February 1919, the judge read aloud the statement given by the mayor of Boğazliyan, Kemal, before the Commission for the Investigation of Evil Acts. In this statement, Kemal describes how he was sent telegrams that ordered him to destroy them after they had been read. ${ }^{112}$ In the hearing of 24 March 1919, when the judge read him his statement, Kemal denied the information with the explanation that he was tired when he wrote it. The prosecutor remarked that Kemal had "thought over [the statement] for about three to four hours" before writing it down. ${ }^{113}$ Finally, I should add that the Katib-i Mesuller did not limit themselves to forming gangs and disseminating the order for annihilation. Their activities also included putting on demonstrations that inflamed the locals' emotions against the Armenians and looting Armenian properties, enriching themselves in the process. In the action brought against them, witnesses were questioned on precisely these types of activities. The final court ruling lists many examples of how the Katib-i Mesuller had inflamed people's emotions (as in the meeting organized by Dr. Mithat in Bolu), seized the 
homes of Armenians, taken over their property and their accounts, and generally organized looting against Armenians. ${ }^{114}$

These documents, taken mostly from the sources numbered (2) to (7) above, openly show the genocidal intent of the Ottoman authorities and can be considered direct evidence of the Armenian Genocide.

\section{Notes}

1. Some of the direct evidence in this article is presented for summary purposes and has already been published. See, for example, Vahakn N. Dadrian, The Armenian Genocide in Official Turkish Records, special issue of Journal of Political and Military Sociology 22, No. 1 (Summer 1994) (reprinted with corrections, Spring 1995). See also Taner Akçam, A Shameful Act: The Armenian Genocide and the Question of Turkish Responsibility (New York: Metropolitan Books, 2006).

2. For more information on the Başbakanllk Arşivi, see www.devletarsivleri.gov.tr. Another important archive is that of the General Staff's Military History and Strategic Studies Institute, or ATASE (Askeri Tarih ve Stratejik Etüd Bakanlığı) in Ankara. The first archive is open to researchers, but the second has many restrictions; if one is able to get access to the ATASE, it is only with great difficulty. The administrators control the materials very strictly and, in most cases, deny the requested files in whole or in part.

3. For a complete list of the sixty-three trials, see Taner Akçam and Vahakn N. Dadrian, "The Protocols of the Istanbul Military Tribunals on the Investigation of the Armenian Genocide" (forthcoming, 2006, in Turkish and English).

4. The memoirs of Aleppo Governor Celal Bey were published in the newspaper Vakit in three installments on 10-13 December (Kanunievvel) 1918. Vehip Pasha's testimony was also published in Vakit, on 31 March 1919. "Circassian Uncle" Hasan's story was published as a series called "Tehçir'in İç Yüzü [The Inside Story of Deportation]" in the newspaper Alemdar, beginning on 19 June 1919 and ending on 28 June 1919 with the eighth installment, despite a statement that it was to be continued. According to an Armenian newspaper, the threat from the CUP against Alemdar caused it to stop publication. Vahakn N. Dadrian, "The Naim-Andonian Documents on the World War I Destruction of Ottoman Armenains: The Anatomy of a Genocide," International Journal of Middle East Studies 18 (1986): p. 353, n. 78.

5. This commission was formed on 23 November 1918 for the purpose of investigating the Armenian deportation and the crimes against Armenians. Vakit and Ikdam, 24 Teşrinisani (November) 1918.

6. For example, Interior Minister Talât's cipher of 10/23 May 1915, reproduced by several Turkish authors, can be found in the original Ottoman-Turkish, and in Armenian script in the archive of the Armenian Patriarchate of Jerusalem. Series 17, Dossier H, nos. 571-72. See Kamuran Gürün, Ermeni Dasyası (Ankara: Türk Tarih Kurumu, 1983), 2218; Kamuran Gürün, The Armenian File (New York: St. Martin's Press, 1985), 210; Muammer Demirel, Birinci Dünya Harbinde Erzurum Ve Çevresinde Ermeni Hareketleri (1914-1918) (Ankara: Generlkurmay, 1996), 52. Telegrams sent from the governor of Mamuretulaziz to the governor's office of Malatya regarding the presence of so many dead in the streets and urging the cleaning of the streets, which was quoted in the indictment of the Main Trial, can be found in Jerusalem. Vehip Pasha's testimony, which was published in Vakit on 31 March 1919, is yet another example.

7. These minutes have been published as a book: Osman Selim Kocahanoglu, IttihatTerakki'nin Sorgulanması ve Yargilanması (Istanbul: Timel, 1998).

8. Unless otherwise indicated, all translations into English are my own.

9. Takvim-i Vekayi, no. 3540; from the first hearing, which took place on 27 April 1919.

10. The final congress of the CUP opened with a speech by Talât Pasha on 1 November 1918 . On 5 November 1918, the party would announce that it was passing into history and would formally dissolve. At the same congress the establishment of the Teceddüt Party 
(Reformation Party) was announced. The constitutional makeup and the assets of the CUP were transferred in total to the new party. The judge at the hearing is questioning Midhat Şükrü about the transfer. Zeki Sarıhan, Kurtuluş Savaşı Günlüğü Mondros'tan Erzurum Kongresine, vol. 1 (Ankara: Öğretmen Yayınları 1986), 19, 25. For more information about the Teceddüt Fırkası, see Tarık Zafer Tunaya, Mütareke Dönemi, vol. 2 of Türkiye'de Siyasal Partiler (Istanbul: Hürriyet Vakfı Yayınları, 1986), 92-138.

11. Takvim-i Vekayi, no. 3543, 4 May 1919.

12. Ibid.

13. Ibid., no. 3540.

14. SSevket Süreyya Aydemir, Makedonya'dan Ortaasya'ya Enver Pasha, vol. 3, 1914-1922 (Istanbul: Remzi Kitabevi, 1978), 468.

15. The telegram of Ahmet Izzet Pasha was issued on 11 November and sent by way of the Berlin Consulate for the German state. AA.Türkei 158/21, A48179.

16. BOA/DH/ŞFR, 54-100, coded telegram from Interior Minister Talât dated 22 June 1915.

17. Takvim-i Vekayi, no. 3540.

18. Ikdam, 11 February 1919.

19. Alemdar, 25 March 1919.

20. UK Foreign Office [FO] 371/4172/31307, report dated 10 February 1919.

21. From the archives of the Armenian Patriarchate of Jerusalem, Carton 21, File M, no. 494.

22. Renaissance, 6-7 March 1919. Renaissance was a French-language newspaper published in Istanbul.

23. Takvim-i Vekayi, no. 3573, from the hearing on 3 June 1919 (published 12 June 1919).

24. Alemdar, 5-6 August 1919. According to the Armenian newspaper Joghovurt, 6 August 1919, the order was meant for documents dealing with the deportation and massacres; cited in Vahakn N. Dadrian.

25. Hüsamettin Ertürk, "Milli Mücadele Senelerinde Teşkilat-1 Mahsusa" (typescript), 14, "Ankara Stratejik Araştırmalar ve Askerlik Tarihi Enstitüsü" (undated). Transcribed by Bilge Criss, Işgal Altında Istanbul (Istanbul: Iletișim, 1983), 147.

26. FO 371/4172/31307, folio 385, from the report of Heathcote Smith, 4 February 1919.

27. R.H. Karay, Minelbab Ilelmihrab (Mütareke Devri Anılarl) (Istanbul: Inkilap Kitabevi, 1992), 271-72.

28. FO 371/4174/15450, folio 182, transcribed in V.N. Dadrian, "Documentation of the Armenian Genocide in Turkish Sources," in Genocide: A Critical Bibliographic Review, vol. 2, ed. Israel W. Charny, 86-138 (London: Mansell Publishing; New York: Facts on File, 1991), 105, facsimile.

29. FO 371/4174/102551, folios 108-111, transcribed in Dadrian, ibid.

30. I will deal with the documents from category (1) in a subsequent article.

31. Celal Bayar, Ben de Yazdım, vol. 5 (Istanbul: Baha Matbaası, 1967), 1573.

32. Menteşe held important posts during the war years, such as parliamentary president, and different posts in cabinet (foreign minister, ministry of justice, etc.)

33. Cemal Kutay, Birinci Dünya Harbi'nde Teşkilât-1 Mahsusa ve Heyber'de Türk Cengi (Istanbul: Ercan matbaasi, 1962), 10.

34. From the memoirs of Kuşçubaşı Eşref, who was in charge of running the "liquidation" operation to rid Anatolia of "not-Turcic" elements, as described in Bayar, Ben de Yazdım, 1578.

35. Cemal Kutay, Türkiye Nereye Gidiyor? (sohbetter \#10) (Istanbul, Halk Matbaası, 1969), 69.

36. Halil Menteş, Osmanlı Mebusan Meclisi Reisi Halil Menteşe'nin Anıları (Istanbul: Hürriyet Vakfi Yayınları, 1986), 165.

37. Cemal Kutay, Birinci, 18.

38. Since I have written extensively on this subject elsewhere, here I will not go into details of the plan and the preparations for it. See Akçam, A Shameful Act.

39. Cemal Kutay, “Türkiye Nereye Gidiyor?”, 69. 
40. The IAMM was established at the beginning of 1914 within the Ministry of the Interior. On 14 March 1916, this office was transformed by a law that granted it expanded authority, after which it comprised many sub-offices. It would grow in power and influence as the years wore on. This new office was called the Ministry of the Interior's Directorate of Tribes and Immigrants (Aşair ve Muhacirin Müdüriyet Umumiyesi, hereinafter AMMU).

41. BOA/DH/ŞFR, 37-1332-C25, coded telegram from Interior Minister Talât to the province of Aydın, 21 May 1914.

42. BOA/DH/ŞFR, 42-158-1332, telegram from the Ministry of the Interior (Bâb-i Ali Dahiliye Nezareti IAMM) to the Regional Office of Aydın, Governorship of Çanakkale (Kale-i Sultaniyeve karesi Mutasarrıflı̆̆), 30 July 1914.

43. BOA/DH/ŞFR, 63-172, coded telegram from Talât Pasha to the regional office in Diyarbakir, 2 May 1916.

44. BOA/DH/ŞFR, 63-187, telegram from Interior Minister Talât, 4 May 1916, quoted in Fuat Dundar, Ittihat ve Terakki’nin Müslümanlari Iskan Politikass (1913-1918) (Istanbul: Iletişim Yayınları, 2001), 141-42.

45. The aim of this article is not to deal with the general population policy of that time. For this aspect of the problem, see Dündar, ibid.

46. BOA/DH/ŞFR, 46-78, coded telegram from the Ministry of the Interior to the regional offices at Van, (26 September 1914).

47. BOA/DH/ŞFR, 63-188-1334.B.1, telegram from the Office of Tribal Refugees (IAMM) to Ankara, Konya, Kayseri, Niğde, and other regional and governors' offices, 13 May 1916.

48. Arnold J. Toynbee, The Western Question in Greece and Turkey (Boston: Houghton Mifflin, 1923), 140, 143, 280; Henry Morgenthau, Ambassador Morgenthau's Story (Garden City, NY: Doubleday, Page, 1918), 212. This relationship needs to be the subject of further examination.

49. The summary appears in Demirel, Birinci Dünya Harbinde, 53. Sources that mention the document are Gürün, Ermeni Dosyası, 277-78; Azmi Süslü, Ermeniler ve 1915 Tehcir Olayı (Van: Yüzüncü Yıl Üniversitesi Rektörlüğü Yayını, 1990), 110.

50. Ati, 24 February 1920.

51. Demirel, Birinci Dünya Harbide, 53.

52. Ati, 24 February 1920 (emphasis added): “Devlet-i Aliyye'nin Fihrist-i Mesail-i Hayatiyyesi arasında mühim bir fasıl iştigâl olan bu gailenin esâshı bir suretde hal ve fash ile külliyen izâlesi esbâbının tehiyye ve ihzârı tasavvur ve mülâhaza edilmekde iken...."

53. Henry Morgenthau, United States Diplomacy on the Bosphorus: The Diaries of Ambassador Morgenthau, 1913-1916 compiled by Ara Sarafian (London: Taderon Press with Gomidas Institute, 2004), 273.

54. Takvim-i Vekayi, no. 3540.

55. Memoirs of Aleppo Governor Celal, Vakit, 12 December 1918.

56. It is important to note here that there is a striking similarity between this letter by Bahaeddin Şakir, sent to Yalman, and other letters attributed to Şakir by Aram Andonian. See Aram Andonian, The Memoirs of Naim Bey (Newton Square, PA: Armenian Historical Research Association, 1965), 49-52.

57. Ahmet Emin Yalman, Turkey in the World War (New Haven, CT: Yale University Press, 1930), 220. The same letter by Şakir is described by Yalman in another work: Ahmet Emin Yalman, Yakin Tarihte Gördüklerim ve Geçirdiklerim, vol. 1 (1988-1918) (Istanbul:

Yenilik Basımevi, 1970), 332. The critical comments that appear in his English work do not appear in the Turkish one.

58. Yalman, Turkey in the World War, 220.

59. Takvim-i Vekayi, no. 3540.

60. Written statement of Vehip Pasha to the Commission for the Investigation of Evil Acts of the Office of General Security, 12 December 1918. The copy in my possession is located at the Armenian Patriarchate of Jerusalem, carton 7, file H, no. 171-82. This statement by Vehip Pasha played an important role not only in the Main Trial but also in the 
Trabzon and Harput trials. The entire statement was read into the record during the second hearing of the Trabzon trial on 29 March 1919 and was incorporated into the court ruling for the Harput Trial.

61. Ibid.

62. M.M.Z.C., Cycle 3, Assembly Year 5, vol. 1, 11 Kanunievvel (December) 1918, 24th Session, p. 300.

63. Takvim-i Vekayi, no. 3540, first hearing (indictment), 27 April 1919.

64. Ibid.

65. Archives of the Armenian Patriarchate of Jerusalem, carton 17, file H, no. 616 .

66. Ibid., carton 21, file M, no. 511.

67. Ibid. For information on the ninth hearing, see accounts in Renaissance, Yeni Gün, and Ikdam from 23 February 1919.

68. Archives of the Armenian Patriarchate of Jerusalem, carton 21, file M, no. 506; Renaissance, 7 March 1919.

69. Just two examples: Grosses Hauptquarteer 194, Türkei 41/1, telegram from Count WolffMetternich to Foreign Minister Javo, 1 July 1916; PA/AA/R 14094, report from Scheubner Richter, 4 December 1916.

70. PA/AA/Bo.Kons./Band 169, report from Head Consulate officer Holleg Mordtmann, 30 June 1915.

71. PA/AA/Bo.Kons./Band, report from Colonel Stange to German embassy in Istanbul, 23 August 1915.

72. See Akçam, A Shameful Act.

73. A. Mil, "Umumi Harpte Teşkilat-1 Mahsusa," Vakit Gazetesi (10 February 1934), installment no. 98.

74. "By putting them [the documents obtained] before the attention of the Union and Progress Central Committee, Dr. Bahaeddin Şakir Bey was occupied with the arguments in favor of taking precautions to save the army from a very serious threat." Ibid. (12 February 1934), installment no. 100.

75. Ibid., installment no. 98.

76. Ibid., installment no. 100.

77. BOA/DH/ŞFR, 51-215, 1333CA20. I thank Fuat Dundar for bringing this document to my attention.

78. I would like to emphasize that here I am only discussing the subject of annihilation during the deportation. Prior to this date Armenians were deported and resettled for reasons that were almost exclusively militarily motivated. For more information, particularly about the deportations that started first in Dörtyol and Iskenderun around February 1915 and later in March and April around the Zeytun and Marash regions, see Akçam, A Shameful Act.

79. BOA/DH/ŞFR, 52-93-1333C9, telegram from the Ministry of the Interior to Cemal Pasha, 24 April 1915. For the document also see Prime Minister's State Archives, General Office, Osmanlı Belgelerinde Ermeniler, 23-24.

80. BA/DH/ŞFR, 52-112-1333-C11, coded telegram from the Ministry of the Interior to the governors' offices of Marash, Adana, and Aleppo, 24 April 1915.

81. BOA/DH/ŞFR, 52-253-1333-C21, coded telegram from the Ministry of the Interior to the Governor's Office of Marash, 6 May 1915.

82. BOA/DH/ŞFR, 52-267, coded telegram from the Ministry of the Interior to the governor of Aleppo, 7 May 1915.

83. BOA/DH/ŞFR, 52-338, coded telegram from the Ministry of the Interior to Adana, 11 May 1915.

84. Prime Minister's State Archives, General Office, Osmanlı Belgelerinde, Ermeniler, p. 28.

85. Ragıp Bey, Tarih-i Hayatim (Ankara: Kebikeç Yayınları, 1996), 59-60.

86. J. Lepsius, Der Todesgang des Armenischen Volkes, Bericht über das Schicksal des Armenischen Volkes in der Türkei waehrend des Weltkrieges (Potsdam: Missionshandlung und Verlag, 1919), 43. 
87. Meclisi Ayan Zabit Ceridesi [Register of Assembly Senate Minutes], Devre [Cycle] III, Assembly year 5, vol. 1, p. 123 (Ankara: TBMM Basımevi, 1990). I use here the translation made by Vahakn N. Dadrian, "The Complicity of the Party, the Government, and the Military. Selected Parliamentary and Judicial Documents," Journal of Political and Military Sociology 22, 1 (summer 1994): 29-96, 81.

88. Ikdam, 5 Kanunievvel 1918 (18 December 1918).

89. Written statement of Vehip Pasha, 12 December 1918.

90. An example of this is a telegram sent by Katib-i Mesul Rüştü, from Samsun on 27 May 1919, wherein he confirms that he has formed the gangs needed in his region. Takvim-i Vekayi, no. 3554, 5th hearing, 14 May 1919.

91. Takvim-i Vekayi, no. 3571, 13 Temmuz 1919 (13 June 1919).

92. Takvim-i Vekayi, no. 3772 (Katib-i Mesuller trial, final court ruling, 8 January 1920).

93. For an example, see Takvim-i Vekayi, no. 3549, 4th hearing, 8 Mayıs 1335 (8 May 1919).

94. Takvim-i Vekayi, no. 3557, 6th hearing, 14 Mayıs 1335 (14 May 1919).

95. Archives of the Armenian Patriarchate of Jerusalem, carton 21, file M, no. 492.

96. This information can be found in Takvim-i Vekayi, no. 3772, in the final court ruling dated 8 January 1920 for the Katib-i Mesuller Trial.

97. Archives of the Armenian Patriarchate of Jerusalem, carton 21, file M, no. 494.

98. Renaissance, 7 March 1919.

99. Lepsius, Der Todesgang, 76.

100. Abidin Nesimi, Yılların Içcinden (Istanbul: Gözlem Yayınları, 1977), 39-40.

101. PA-AA/Bo.Kons./Band 169, telegram from Walter Holstein, Vice-Consul of Mosul, to German Embassy in Istanbul, 16 July 1915.

102. Alemdar, 11 May 1919.

103. Hüseyin Cahit Yalçın, Siyasi Anılar (Istanbul: Türkiye İş Bankası Kültür Yayınları, 1976), 236.

104. Takvim-i Vekayi, no. 3549, 8 Mayıs 1335 (8 May 1919).

105. Ibid.

106. Alemdar, 3 August 1919.

107. Takvim-i Vekayi, no. 3771, 9 February 1920, final court ruling from the Mamüretülaziz trial.

108. Takvim-i Vekayi, no. 3540, 27 Nisan 1335 (27 April 1919).

109. FO 371/4172/31307, p. 396, report dated 10 February 1919.

110. Tercümanı Hakikat, 5 August 1920; Vakit, 6 August 1920.

111. Takvim-i Vekayi, no. 3540, 1st hearing, indictment from the Main Trial, 27 Nisan 1335 (27 April 1919).

112. Renaissance, 12 February 1919; Ikdam, 11 February 1919.

113. Alemdar, 25 March 1919.

114. Takvim-i Vekayi, no. 3772, Katib-i Mesuller trial, court ruling dated 8 January 1920. 